\title{
Arhiv za likovne umjetnosti: Dva desetljeća digitalizirane povijesti umjetnosti
}

\section{The Fine Arts Archives: Two Decades \\ of Digitized Art History}


PRETHODNO PRIOPĆENJE

Predan: 2.7.2019.

Prihvaćen: 10.8.2019.

DOI: 10.31664/zu.2019.105.08

UDK: 7.01:[025.8:004(497.5 Zagreb)

\section{SAŽETAK}

Osnovan kao prvi dokumentacijski centar i arhiv za nacionalnu povijest umjetnosti, Arhiv za likovne umjetnosti pri Hrvatskoj akademiji znanosti i umjetnosti kontinuirano razvija svoj informacijski sustav, pružajući podršku stručnjacima i znanstvenoj zajednici. U ovom ćemo radu prikazati povijest procesa automatizacije podataka, koji je započeo 1995. godine-od jednostavnih tablica u MS Excelu i baza podataka u programu MS Access, stvorenih za specifične potrebe Arhiva, do složene repozitorijske platforme otvorenog pristupa, razvijene kao izvor za rastuće područje digitalne povijesti umjetnosti. Digitalna tehnologija kontinuirano stvara nove i brže načine dohvaćanja arhivskih podataka-od jednostavnih pretraživanja pojmova kroz nekoliko izvanmrežnih baza podataka do naprednijih mogućnosti internetskog pretraživanja utemeljenog na semantičkoj mrežnoj tehnologiji. Arhiv za likovne umjetnosti prisutan je na internetu od 2009. preko Digitalne zbirke (DiZbi), institucionalne repozitorijske platforme koja je prvi put uspostavila vezu između digitaliziranih tekstualnih i vizualnih izvora različitih Akademijinih jedinica. Kako bi se digitalni objekti prikazali na što živopisniji i interaktivniji način, stvoren je nov digitalni sadržaj-virtualna izložba, kao jedna od vizualno atraktivnijih odlika portala. Kontinuirani proces digitalizacije arhivske građe otvorio je nove mogućnosti za suradnju s domaćim i međunarodnim ustanovama kroz nekoliko projekata. Budući planovi uključuju dugoročan projekt s potencijalom razvoja u digitalnu infrastrukturu za istraživanje provenijencije. Na temelju svojih iskustava s ovakvim digitalnim projektima možemo reći da stručnjaci za digitalnu povijesti umjetnosti imaju sve važniju ulogu u snažnijoj vidljivosti hrvatske povijesti umjetnosti, kako na nacionalnoj tako i na međunarodnoj razini, kao i u omogućavanju novih oblika digitalne analize u povijesti umjetnosti.

KLJUČNE RIJEČI

arhiv umjetnika, digitalizacija, repozitorijska platforma, virtualna izložba, metapodatkovni standardi, digitalna povijest umjetnosti, istraživanje provenijencije
PRELIMINARY PAPER

Received: July 2, 2019

Accepted: August 10, 2019

DOI: $10.31664 / z u .2019 .105 .08$

UDC: 7.01:[025.8:004(497.5 Zagreb)

\section{ABSTRACT}

Established as the first documentation centre and archive for national art history, the Fine Arts Archives at the Croatian Academy of Sciences and Arts have been continuously developing their information system and support for experts and the scholarly community. In this paper, we will present the history of the Archives' automation process, which started in I995-from simple Excel tables and Access databases created for the Archives' specific needs to a complex open-access repository platform, developed as a resource for the growing field of digital art history. Digital technology has been continuously providing new and faster ways of retrieving archival information-from simple concept searches of several offline databases to the more advanced possibilities of online search based on semantic web technology. The Fine Arts Archives went online in 2009 via DiZbi, an institutional repository platform, which for the first time established connection between the digitized textual and visual sources of different Academy units. In order to present digital objects in a more vivid and interactive way, new digital content has been created through virtual exhibitions as one of the visually appealing portal features. An ongoing process of digitization of archival holdings has opened up new opportunities for collaboration with national and international institutions through several projects. Future plans include a long-term project with the potential of developing into a digital infrastructure for provenance research. Based on our experiences with these digital projects, we argue that art information professionals are playing an increasingly important role in raising the visibility of Croatian art history, both nationally and internationally, and in facilitating new forms of digital art historical analyses.

\section{KEYWORDS}

art archives, digitization, repository platform, virtual exhibition, metadata standards, digital art history, provenance research

\section{Jasenka Ferber Bogdan Andreja Der-Hazarijan Vukić}

Arhiv za likovne umjetnosti Hrvatske akademije znanosti i umjetnosti, Zagreb /

Fine Arts Archives, Croatian Academy of Sciences and Arts, Zagreb 
U ovom radu predstavljeni su rezultati prve dekade digitalizacije arhivskih izvora koje je prikupio i stvorio Arhiv za likovne umjetnosti pri Hrvatskoj akademiji znanosti i umjetnosti, kao i naše spoznaje i razmišljanja proizašla iz ovog iskustva. Informatizacija Arhiva započela je sredinom devedesetih godina, prije prvih digitalnih koraka, čime su stvoreni potrebni preduvjeti za buduću digitalnu obradu raznolike arhivske građe.

Arhiv za likovne umjetnosti osnovan je 1937. godine, u skladu s idejom njegova osnivača dr. Antuna Bauera, kao pomoćna zbirka dokumentacije prvotno vezana uz zbirku Gipsoteke, koja je istodobno uspostavljena s glavnom svrhom pružanja uvida u relevantna djela hrvatskog kiparstva od antike do suvremenog doba. Godine 1943. Arhiv je otvoren za javnost kao dokumentacijsko-informacijski centar za likovne umjetnosti 19. i 20. stoljeća.

S vremenom je Arhiv proširio svoj stručni interes na cjelokupnu domaću umjetničku praksu. U šest zbirki prikupljene su, razvrstane i sistematizirane različite vrste građe poput isječaka iz novina, reprodukcija umjetničkih djela, fotografija, originalnih skica i crteža te arhivske dokumentacije kako bi se olakšao pristup potrebnoj građi. Drugi val sistematizacije i modifikacije zbirki, prema tada vrijedećim europskim standardima, uslijedio je 1950. godine, ulaskom Gipsoteke zajedno s Arhivom za likovne umjetnosti u sklop Jugoslavenske akademije znanosti i umjetnosti, ${ }^{1}$ temeljne ustanove koja ima važno mjesto u stvaranju nacionalnog identiteta kroz promidžbu i razvoj znanosti i kulture. Godine 1952. Arhiv je nakon odvajanja od Gliptoteke ${ }^{2}$ nastavio djelovati kao samostalna istraživačka jedinica pri Institutu za likovnu umjetnost Jugoslavenske akademije. Odabrani i znatno reducirani materijal, iz kojeg su izdvojena originalna umjetnička djela i smještena u galerijske prostore Akademije, dokumentiran je i pohranjen prema novim kriterijima u cilju jasnije definicije zbirki. Tijekom pedesetih godina stručnjaci Arhiva posjetili su nekoliko specijaliziranih europskih arhiva, instituta i dokumentacijskih centara: tako je 1954. Danica Švalba bila na STIA stažiranju u Parizu, kustosica Doris Baričević posjetila je 1956. godine Zentralinstitut für Kunstgeschichte u Münchenu, a 1958. pohađala je i 7. ljetnu školu RKD-a u Haagu. Njihovo dragocjeno iskustvo rezultiralo je modernizacijom Arhiva za likovne umjetnosti, što je uključivalo nov pristup popisivanju, katalogizaciji i razvrstavanju građe unutar osam zbirki. Detaljnom razradom cjelokupnog sustava stvorena je složena, ali funkcionalna struktura s analognom međupovezanošću svih elemenata, koju je kasnije bilo lako „prevesti” u digitalni kontekst, posebice u organiziranju i kreiranju metapodataka.

$\rightarrow$

1 Jugoslavenska akademija znanosti i umjetnosti preimenovana je 1991. godine u Hrvatsku akademiju znanosti i umjetnosti. 2 Gipsoteka je 1952. godine preimenovana u Gliptoteku. 
This paper presents the results of a decade of digitization of archival sources collected and created by the Fine Arts Archives at the Croatian Academy of Sciences and Arts, as well as our findings and thoughts resulting from this experience. The Archives' automation started in the midI990s, before the first digital steps, thus creating the necessary preconditions for the future digital processing of heterogeneous archival material.

The Fine Arts Archives was founded in 1937, in accordance with the idea of its founder, Dr Antun Bauer, as an auxiliary documentation collection primarily related to the Gypsotheque, a simultaneously established collection with the main purpose of providing an overview of the relevant works of Croatian sculpture from ancient to modern times. In 1943, the Archives were opened for public use as a documentation and information centre for the visual arts of the Ioth and 20 th centuries.

Over time, the Archives extended its professional interest to the entire national art practice. Various kinds of material, such as newspapers clippings, reproductions of artworks, photographs, original sketches and drawings, and archival documentation were collected, sorted, and systematized within six collections to facilitate access to the required documentation. The second wave of systematization and modification of the collections, according to the then applicable European standards, followed in I950, with the entry of the Gypsotheque along with the Fine Arts Archives in the Yugoslav Academy of Sciences and Arts, ${ }^{1}$ a fundamental institution that has a major place in constituting national identity through support and development of science and culture. In I952, the Archives were separated from the Glyptotheque ${ }^{2}$ and continued as an independent work facility of the Institute of Fine Arts at the Yugoslav Academy. Selected and significantly reduced material, from which original art works had been extracted and placed in the Academy's gallery units, was recorded and stored according to the new criteria aiming at a clearer definition of collections. During the I950s, the Archives' professionals visited several European specialized archives, institutes, and documentation centres: in I954, Danica Švalba received a STIA internship in Paris; in I956, curator Doris Baričević visited the Zentralinstitut für Kunstgeschichte in Munich; and in 1958 , Baričević attended the 7 th RKD Summer School in the Hague. Their valuable experience resulted in modernization of the Fine Arts Archives, which included a new approach to inventorying, cataloguing, and sorting the materials within the eight collections. With a detailed elaboration of the entire system, a complex but functional structure - the analogous interconnectedness of all elements - was created. Later on, it was easily "translatable" into the digital context, especially in organizing and creating metadata.

Yugoslav Academy of Sciences and Arts changed its name $\rightarrow$ 
PREDDIGITALNO

DOBA: POČECI AUTOMATIZACIJE

Organizacija podataka temeljila se na nekoliko arhivskih zbirki - bibliografiji, osobnim i institucionalnim arhivima, zbirci fotografija, katalozima izložbi i specijaliziranoj knjižnici. Proces sistematizacije podataka rezultirao je stvaranjem pomagala za pretraživanje zbirki poput kartona umjetničkih izložbi i kartona umjetnika, strukturiranih prema strogo definiranom sustavu metapodataka. Na taj su način podaci o izložbama povezani s datotekama umjetnika i drugim arhivskim zbirkama: katalozima, fotografijama, bibliografijom, arhivom umjetnika i institucija. Ovaj dobro strukturirani sustav organiziranih metapodataka stvorio je solidnu polazišnu točku za planiranje procesa automatizacije. Prvi takav projekt pokrenut je 1995. godine, uz podršku sustava za upravljanje podacima FoxPro, kao prvi pokušaj stvaranja nacionalne baze podataka na području povijesti umjetnosti. Unatoč prekidima u projektu 1996. godine, uzrokovanima zatvaranjem informatičke tvrtke koja je angažirana na projektu, bila je to prekretnica u shvaćanju širokih mogućnosti koje otvara kompjutorizacija arhivskih podataka.

Odlučni u namjeri da nastavimo proces, iako bez dovoljne tehničke i financijske podrške, krajem devedesetih odlučili smo upotrijebiti dostupne programske alate (MS Microsoft Excel i Access), koje smo prilagodili specifičnim potrebama postojećega informacijskog sustava Arhiva. Osnova ovog novog sustava bila je baza imena umjetnika, s više od četrnaest tisuća likovnih umjetnika s područja bivše Jugoslavije, učitanih u Excelove tablice, s osnovnim metapodacima (ime, zanimanje, lokacija, godine rođenja i smrti). Uslijedile su ostale zbirke-korespondencija umjetnika, zbirka fotografija i drugi arhivski izvori-kao priprema za budući prijenos u digitalni oblik.

Sljedeći je korak bio uvoz datoteka umjetnika iz Excelovih tablica u Access, čime je stvorena relacijska baza podataka umjetnika i njihovih izložbi. U procesu stvaranja baze podataka koja će biti posebno prilagođena potrebama Arhiva za likovne umjetnosti konzultiran je informacijski stručnjak. Unos podataka u novoosmišljenu bazu započet 2008. godine i danas je način dokumentiranja izložbi, omogućavajući daleko bržu i jednostavniju obradu, kvantifikaciju i statistički pregled podataka. Unatoč svoje jednostavnosti, program Access omogućuje povezivanje podataka kroz različite upite, izradu završnih izvješća i slično.

\section{PRE-DIGITAL ERA : \\ THE BEGINNINGS OF AUTOMATION}

Data organization was based on several archival collections - bibliography, personal and institutional archives, a photograph collection, exhibition catalogues, and a specialized library. The data systematization process resulted in the creation of search aids for collections such as art exhibitions or artists' files, structured within a strictly defined metadata system. In that way, the exhibition data were interconnected with the artists' files and other archival collections: catalogues, photographs, bibliography, artists' and institutional archives. This well-structured system of organized metadata provided a solid starting point for planning the automation process. The first such project was launched in I995, supported by the data management system FoxPro, as the first attempt at creating a national art history database. Despite the disruption in the project in I996, caused by the closure of the IT company to which it had been outsourced, this was the turning point in comprehending the wide possibilities of computerizing archival data.

Determined to continue the process, but without sufficient technical and financial support, in the late I990s we decided to work with the available software (Microsoft Excel and Access) and adjusted it to respond to the specific needs of the Archives' existing information system. The base of this new system was a list of artist names, which consisted of more than 14,000 visual artists from former Yugoslavia, translated into Excel sheets, with the basic metadata containing the name, affiliation, location, and years of birth/death of each artist. Other collections followed - the artists' correspondence, the photograph collection, and other archival resources - as a preparation for future transfer into digital form.

The next step was to import the files on the artists from Excel tables to Access, thus creating a relational database of artists and their exhibitions. In the process of creating a database specifically tailored to fit the Fine Arts Archives' needs, an outsourced IT expert was consulted for help and support. Started in 2008, this became the main input method in exhibition recording, enabling much faster and easier data processing, quantification, and statistical overviews. In addition, as basic as it was, the Access system made it possible to link data through various queries, creation of final reports, etc. 


\section{DIGITALIZACIJA: OD ZAŠTITE}

DO OTVORENOG PRISTUPA

\section{DIGITIZATION : FROM \\ PRESERVATION TO OPENNESS}

Prva faza digitalizacije započeta je s katalozima izložbi odabranima prema uobičajenim kriterijima-vrijednosti, stanju i učestalosti manipulacije. Izabrana građa uključivala je kataloge starijih izložbi od 1890. do kraja 40-ih godina 20. stoljeća, čime je formiran korpus od više od 400 objekata prve mrežne zbirke digitaliziranih tekstova s područja hrvatske povijesti umjetnosti. Uz važnije samostalne izložbe naglasak je stavljen na umjetničke skupine i pokrete koji su utjecali na važne promjene u hrvatskoj umjetnosti (Hrvatsko društvo umjetnosti, Proljetni salon, Zemlja, Grupa trojice). Digitalna zbirka postupno je proširivana uvođenjem objekata iz zbirke fotografija (umjetnici, radovi, izložbe) i arhivskih zbirki (Arhiv Galerije Studentskog centra, Arhiv Salona Ullrich) (sl. 1).

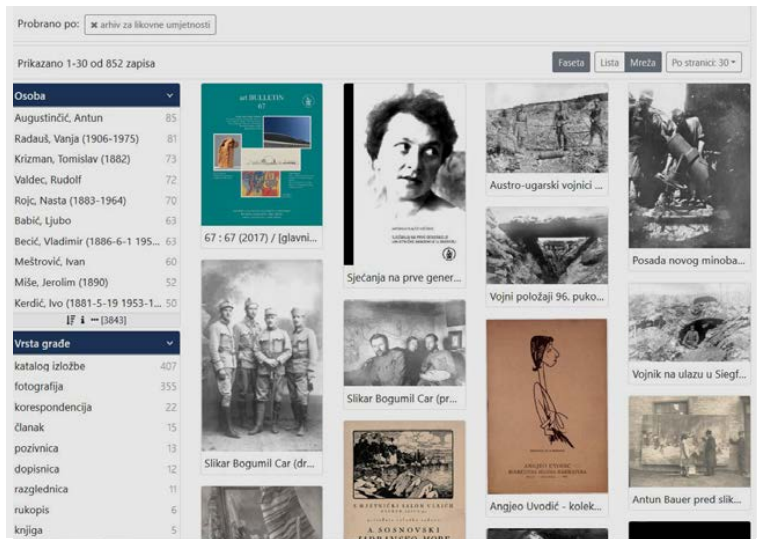

Slika 1. Digitalizirana građa Arhiva za likovne umjetnosti na DiZbi sučelju. (Izvor: https://dizbi.hazu.hr/a/?pr=I\&msq=arhiv+za+likovne +umjetnosti\&view=grid\&page=1). / Figure I. Front-end of Fine Arts Archives digital content at DiZbi. (Source: https://dizbi.hazu.hr/a/?pr= l\&msq=arhiv+za+likovne+umjetnosti\&view=grid\&page=I).

3 See: "DiZbi.HAZU." 4 The software solution for the ArhivX platform was developed by the ArhivPRO company. 5 The Fine Arts Archives, the Division for the History of Croatian Theatre, the Division for the History of Croatian Music, and the Academy Library as the initiator established the Digital Collection.

Today, the following units contribute to DiZbi: Academy Library as its coordinator, Fine Arts Archives, Glyptotheque, Croatian Museum of Architecture, Croatian Museum of Medicine and Pharmacy, Adriatic Institute, Department of Prints and Drawings, Institute of Historical and Social Sciences-Division for Ethnology, Institute for the History of Croatian Literature, Theatre and Music-Division for the History of Croatian Music, Division for the History of Croatian Literature, Division for the History of Croatian Theatre, Institute for the History and Philosophy of Science-Division for the History of Medical Sciences, Strossmayer Gallery of Old Masters, Institute for Scientific and Artistic Work in Osijek, and Institute for Scientific Work in Varaždin. 7

"Croatian Smart Specialisation Strategy 20I6.-2020."
The first phase of digitization started with the exhibition catalogues selected according to the common criteria - value, condition, and frequency of manipulation. The chosen materials included early exhibition catalogues from I890 to the late I940s, which formed a corpus of more than 400 items as the first online collection of digitized Croatian art history texts. In addition to the main solo exhibitions, emphasis was placed on art groups and movements that had caused important shifts in Croatian art history (Hrvatsko društvo umjetnosti, Proljetni salon, Zemlja, Grupa trojice). The digital collection was gradually expanded by introducing items from the photograph (artists, artworks, exhibitions) and archival collections (Archives of the Student Centre Gallery, Salon Ullrich Archives) (Fig. I).

Simultaneously, in 2008, an institutional digitization project was initiated by the Academy Library. Established to gather digitized materials from the Academy's research units and GLAM institutions, the Digital Collection of the Croatian Academy of Sciences and Arts (DiZbi) was launched online in $2009{ }^{3}$ technically supported by the ArhivX platform, with the aim of serving as a unique institutional repository platform with free online access. ${ }^{4}$ The Fine Arts Archives were among the first few units to contribute to the repository, ${ }^{5}$ which soon became one of the leading digital platforms of its kind in Croatia. DiZbi currently comprises digitized objects from fifteen Academy departments' collections with various original formats: books and journals, art exhibition catalogues, manuscripts, sculptures, cast sheets, plaster casts, medals and plaques, paintings, photographs, posters, and more. ${ }^{6}$ According to the Academy's open data support, there is free public access to the majority of the digital media, with the Europeana licensing standards implemented for each digital object. Due to the existing content diversity, the platform, which offers valuable resources for Croatian cultural history, also has the ability to support interdisciplinary research. However, without a dedicated digitization strategy and funding at the state level, the planned progress of the platform is periodically interrupted, leading to slowdowns in software improvement and addition of new digitized content. For example, the Smart Specialization Strategy $(\mathrm{S} 3),{ }^{7}$ a document that is a major precondition for withdrawing resources from the EU funds, does not contain any goal or activity related to digitization of Croatian cultural heritage. Furthermore, the lack of digital education prevents researchers from making full use of DiZbi and similar platforms, since there are only a few university courses in digital humanities in Croatia.

The openness of the Fine Arts Archives collections through the online platform has made the collections more widely visible to national and international researchers, resulting in an increased scholarly interest in Croatian artists and art groups. In the past few years, precisely because of the presence of selected digitized artefacts on an open 
Istodobno je 2008. godine Knjižnica Hrvatske akademije pokrenula institucionalni projekt digitalizacije. Ustanovljena radi prikupljanja digitaliziranih materijala iz istraživačkih jedinica Akademije i AKM ustanova, Digitalna zbirka Hrvatske akademije znanosti i umjetnosti (DiZbi) objavljena je na internetu 2009. godine ${ }^{3}$ uz tehničku podršku platforme ArhivX, u cilju da služi kao jedinstvena institucionalna repozitorijska platforma uz slobodan pristup. ${ }^{4}$ Arhiv za likovne umjetnosti bio je među prvim jedinicama koje su dale svoj doprinos repozitoriju, ${ }^{5}$ koji je ubrzo postao jedna od vodećih digitalnih platformi ove vrste u Hrvatskoj. DiZbi trenutačno sadrži digitaliziranu građu fizičkih objekata iz petnaest zbirki Akademijinih odjela u različitim izvornim formatima: knjige i časopise, kataloge izložbi, rukopise, skulpture, sadrene odljeve, medalje i plakete, slike, fotografije, plakate i drugo. ${ }^{6} \mathrm{U}$ skladu s Akademijinom politikom otvorenog pristupa podacima, većini digitalnog sadržaja moguće je pristupiti javno i besplatno, uz primjenu licencnih standarda Europeane za svaki pojedini digitalni objekt. Zahvaljujući svojoj raznolikosti, sadržaj pohranjen na platformi nudi vrijedne izvore za hrvatsku kulturnu povijest podržavajući interdisciplinarna istraživanja. Međutim, bez namjenske strategije digitalizacije i financiranja na državnoj razini, planirani napredak platforme povremeno se prekida, što dovodi do usporavanja u poboljšanju programskog alata i dodavanju novih digitaliziranih sadržaja. Primjer je koji potvrđuje nedostatak strategije digitalizacije hrvatske kulturne baštine Smart Specialization Strategy(S3), ${ }^{7}$ strateški dokument Republike Hrvatske za dobivanje sredstava iz fondova EU-a, koji ne sadrži nijedan cilj ili djelatnost povezanu s digitalizacijom hrvatske kulturne baštine. Jednako tako, nedostatak digitalne pismenosti sprječava istraživače da u potpunosti iskoriste DiZbi i slične platforme, s obzirom na to da u Hrvatskoj postoji samo nekoliko sveučilišnih kolegija digitalne humanistike.

Otvorenost zbirki Arhiva za likovne umjetnosti kroz internetsku platformu povećala je njihovu vidljivost za domaće i strane istraživače, što je rezultiralo i snažnijim znanstvenim interesom za hrvatske umjetnike i umjetničke skupine. U posljednjih nekoliko godina, upravo zbog prisutnosti odabranih digitaliziranih sadržaja na otvorenoj platformi, sve veći broj stranih znanstvenika istražuje Arhiv. ${ }^{8}$ Uzevši u obzir ovu tendenciju, odlučivanje o odabiru građe za digitalizaciju i stvaranje složenih metapodataka postaje sve važnijim aspektom rada stručnjaka za digitalnu povijest umjetnosti u Arhivu, olakšavajući time pozicioniranje hrvatske umjetnosti i umjetnika unutar regionalne i globalne povijesti umjetnosti (sl. 2). platform, there have been a growing number of international researchers working at the Archives. ${ }^{8}$ Considering this tendency, the decision-making processes for selecting material for digitization and producing complex metadata have become an increasingly important aspect of work for the art information professionals at the Archives, thereby facilitating the positioning of Croatian art and artists within regional and global art history (Fig. 2).

$\rightarrow$
3 Vidi: „DiZbi.HAZU”. 4 Programski alat za platformu ArhivX razvila je tvrtka ArhivPRO. 5

Osnivači Digitalne zbirke bili su Arhiv za likovne umjetnosti, Odsjek za povijest hrvatskog kazališta, Odsjek za povijest hrvatske glazbe i Akademijina knjižnica.

Danas u Digitalnoj zbirci sudjeluju sljedeće sastavne jedinice: Knjižnica kao koordinator, Arhiv za likovne umjetnosti, Gliptoteka, Hrvatski muzej arhitekture, Hrvatski muzej medicine i farmacije, Jadranski zavod, Kabinet grafike, Zavod za povijesne i društvene znanosti-Odsjek za etnologiju, Zavod za povijest hrvatske književnosti, kazališta i glazbe-Odsjek za povijest hrvatske glazbe, Odsjek za povijest hrvatske književnosti, Odsjek za povijest hrvatskog kazališta, Zavod za povijest i filozofiju znanosti-Odsjek za povijest medicinskih znanosti, Strossmayerova galerija starih majstora, Zavod za znanstveni i umjetnički rad u Osijeku i Zavod za znanstveni rad u Varaždinu.

7

„Croatian Smart Specialisation Strategy 2016.-2020.”.

Na primjer, kao rezultat istraživanja Marka Ilića, digitalizirana građa iz Arhiva Studentskog centra objavljena je u e-knjizi Collaboration and its (dis)contents (2016.), u izdanju Courtauld Institute of Art, te nedavno u Ilićevu članku u časopisu ARTMargins. Vidi: Gotti, Ilić, „Point of Origin: from a History of Alternative Art to a History of Alternative Institutions”; Ilić, „Made in Yugoslavia. Struggles with Selfmanagement in the New Art Practice, 1965-71". 
IZGRADNJA

METAPODATKOVNIH STANDARDA

Na platformi DiZbi metapodaci za digitalizirane sadržaje strukturirani su u skladu s trenutačnim međunarodnim podatkovnim standardima (UNIMARC, EAD, CIDOC itd.) i u sklopu nekoliko modela razvijenih za potrebe specifičnih kolekcija (skulptura, notni zapis, slika, fotografija, katalog, časopis, rukopis itd.). Standardizirani setovi metapodataka, kao što su kontrolirani rječnici zemljopisnih i osobnih imena, uvoze se na platformu kako bi se izbjeglo rasipanje i umnažanje sličnih varijanti. Prethodno sastavljena baza podataka imena umjetnika u Arhivu za likovne umjetnosti agregirana je i objedinjena s bazom podataka osoba koju je izradila Knjižnica. DiZbi je trenutačno u procesu prijelaza s ArhivX-a na INDIGO, hibridnu repozitorijsku platformu koja se temelji na semantičkim tehnologijama, čime će se normativne baze podataka uskladiti i povezati na funkcionalniji način. Budući da je DiZbi osmišljen kao transdisciplinarna platforma koja povezuje knjižnice, arhive i muzejsko-galerijske odjele, metapodatkovni modeli moraju biti pažljivo strukturirani, s mogućnošću opisivanja različitih digitalnih sadržaja. Svaki zapis sadrži nekoliko vrsta metapodataka kao sastavne komponente: opisni (koji podržava otkrivanje i lociranje digitalnih izvora), strukturni (kontekst, odnos s drugim digitalnim sadržajima), tehnički (koji automatski stvara programski alat platforme) i zakonodavni (propisi o pravima).
At the DiZbi platform, metadata for digitized objects are structured in accordance with the current international data standards (UNIMARC, EAD, CIDOC etc.), forming several models and developed to meet the needs of specific collections (sculpture, musical composition, painting, photography, catalogue, journal, manuscript, etc.). Standardized metadata sets, such as controlled vocabularies of geographical and personal names, are imported on the platform in order to avoid dispersion and multiplication of similar variants. The Fine Arts Archives' previously created list of artist names has been aggregated and merged with the Library's list of persons. DiZbi is currently in the process of transitioning from ArhivX to INDIGO, a hybrid repository platform based on semantic technologies, which will harmonize and link the normative databases in a more functional way. Since DiZbi is created as a cross-disciplinary platform, joining the library, archives, and museum/gallery departments, metadata models have to be carefully structured, with the ability to describe various digital objects. As an integral component, every record contains several types of metadata: descriptive (supporting the discovery and locating of digital resources), structural (context, relationship with other digital items), technical (automatically created by the platform software), and legislative (the rights regulations).

Bućan, Boris: Priprema Izložbe Bućan-Art, Galerija Studentskog centra, 9.- 24. veljače 1973 [Dabac, Petar] $\mathbf{1}$

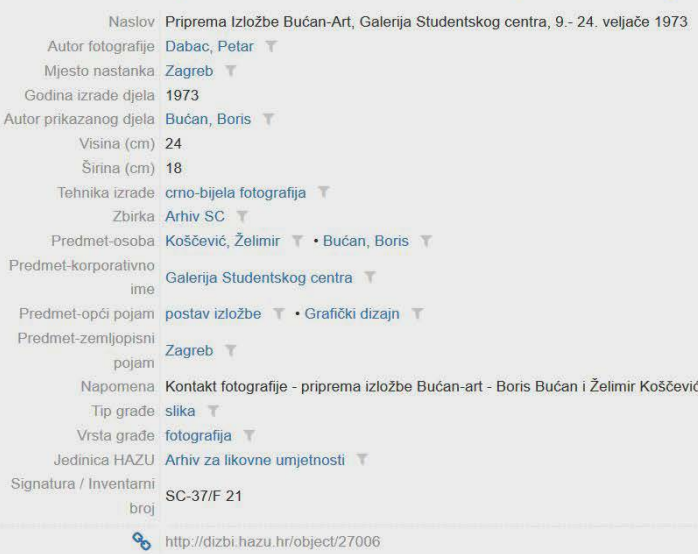

Slika 2. Set metapodataka za digitaliziranu fotografiju (Priprema izložbe Bućan Art, Galerija Studentskog centra, 1973., Arhiv Galerije Studentskog centra, foto: Petar Dabac). (Izvor: http://dizbi.hazu.hr/object/27006) / Figure 2. Metadata set for digitized photo (Preparation for Bućan Art exhibition, Studentski centar Gallery, I973, Archives of Studentski centar Gallery, Fine Arts Archives, photo: Petar Dabac). (Source: http://dizbi.hazu.hr/ object/27006) $\uparrow$

For example, as a result of Marko Ilić's research, digitized material from the Archive of the Student Centre was published in the Courtauld e-book Collaboration and its (dis)contents (20I6), and more recently in an article in the journal ART Margins. See: Gotti, Ilić, "Point of Origin: from a History of Alternative Art to a History of Alternative Institutions;" Ilić, "Made in Yugoslavia. Struggles with Self-management in the New Art Practice, 1965-7I.” 
VIRTUALNE IZLOŽBE:

KREATIVNA NTERPRETACIJA DIGITALNOG

SADRŽAJA

U svrhu poboljšanja prezentacije sadržaja DiZbija 2013. godine pokrenut je multimedijski projekt dvojezičnih virtualnih izložbi kao dodatna mogućnost diseminacije digitalnog sadržaja. Mogućnost stvaranja različitih tematskih virtualnih izložbi pokazala se kao korisno sredstvo u promicanju knjižničnih i arhivskih fundusa koje se obično smatra manje važnima u konvencionalnim izložbenim projektima (fotografije, prepiska, arhivski dokumenti itd.). U usporedbi s fizičkom izložbom, virtualna izložba ima određene prednosti zbog neograničenog trajanja i mogućnosti naknadnog mijenjanja sadržaja, što je čini optimalnim rezultatom uloženog rada i vremena osoblja i kustosa. Internetska prezentacija tematski organizirane arhivske građe kao nadopuna aktualnih izložbi, obljetnica ili kulturnih događaja omogućuje aktivnije uloge Digitalne zbirke u stvaranju novih kulturnih sadržaja. Pripreme za postavljanje takve izložbe još uvijek zahtijevaju uobičajene kustoske prakse, bez obzira na vrstu medija: ideju, sinopsis, odabir predmeta, predmetne legende, skede i slično.

Pablo Picasso: Proslava 80. rođendan-Vallauris $1961 .^{9}$ bila je prva Akademijina virtualna izložba koju je organizirao kustoski tim Arhiva za likovne umjetnosti, a predstavila je odabrane fotografije koje je na slavljeničkom događaju snimila hrvatska povjesničarka umjetnosti Vesna Barbić. Budući da građa opisuje događaj koji se zbio u određenom vremenskom okviru, struktura izložbe i izbor fotografija i dokumenata organizirani su na način koji je naglasio tu narativnu crtu. Virtualna izložba postavljena tijekom fizičke izložbe Picasso-Remek-djela iz Muzeja Picasso u Parizu (Zagreb, Galerija Klovićevi dvori) privukla je veliku pozornost javnosti, a uključena je i među izložbe Europeane 2014. Dvije godine kasnije, za trajanja izložbe Picasso, a Genius without a Pedestal (MuCEM, Marseille), ${ }^{10}$ ta je virtualna izložba ponovno došla u žarište interesa te je predstavljena u lokalnom kulturnom časopisu. ${ }^{11}$

Druga virtualna izložba, Prvi svjetski rat-iz zbirki Hrvatske akademije znanosti i umjetnosti, ${ }^{12}$ bila je nadahnuta stotom obljetnicom završetka Prvoga svjetskog rata, a okupila je šest Akademijinih jedinica i njihove funduse čija su zajednička nit osobna svjedočanstva o ratnim zbivanjima s različitih gledišta i temeljem različitih iskustava, uključujući po jednog umjetnika, liječnika, arhitekta i vojnika.

Najnovija izložba Arhiva za likovne umjetnosti postavljena je 2018. godine: Arhiv Salona Ullrich, prva privatna umjetnička galerija u Zagrebu (sl. 3). ${ }^{13}$ Izložba je dio višegodišnjeg projekta Digitalizacija Arhiva Salona Ullrich, kojom je dan pregled raznovrsne arhivske građe (knjige primitaka i izdataka, inventare, prepisku, izložbenu dokumentaciju, osobne fotografije).

Osim prilike da se arhivska građa predstavi daleko široj publici, virtualni izložbeni projekti omogućavaju stručnjacima

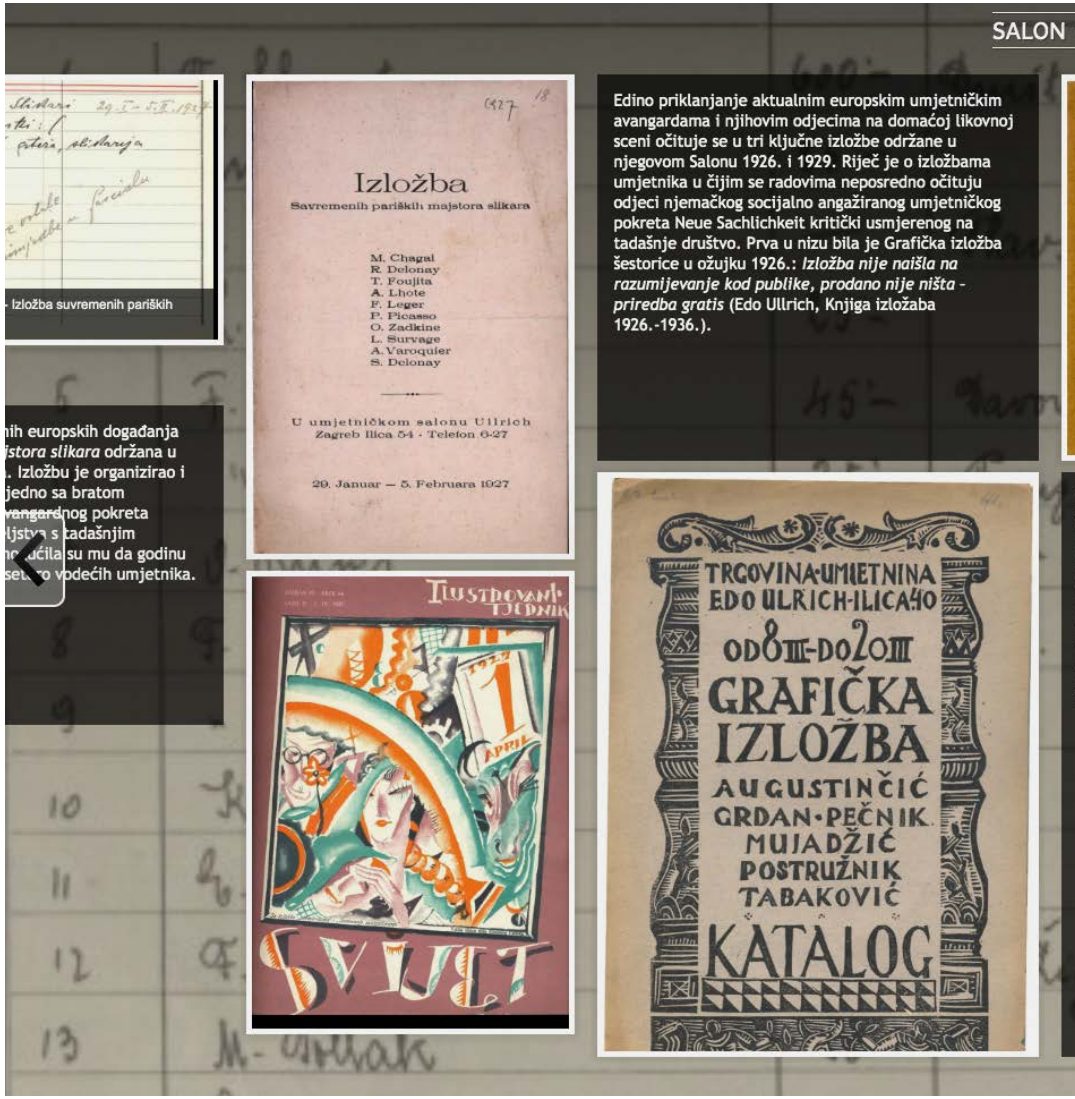

Slika 3. Virtualna izložba Salon Ullrich, prva zagrebačka privatna galerija (detalj), objavljena 2018. (Izvor: http://dizbi.hazu.hr/ullrich/) / Figure 3 Virtual exhibition Ullrich Salon Archives, the first Zagreb private art gallery (detail), launched in 20I8. (Source: http://dizbi.hazu.hr ullrich/)

$\uparrow$

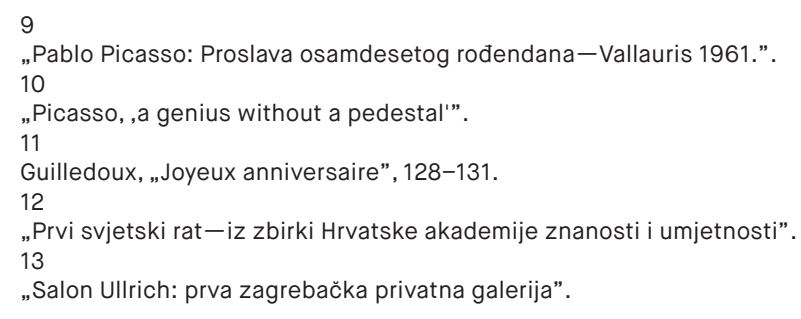


baštinskih ustanova da postanu „pripovjedači” koji će subjektivno odabrati određeni sadržaj i iznijeti ga pred javnost, imajući u vidu svoju profesionalnu odgovornost da predstave pouzdane i vrijedne arhivske izvore.

\section{PROJEKTI SURADNJE: OD DOMAĆIH DO MEĐUNARODNIH}

Proces digitalizacije Akademijinih fondova stvorio je nove mogućnosti za suradnju s domaćim i stranim ustanovama kroz nekoliko projekata. DiZbi je bio jedan od davatelja metapodataka za Europeana Cloud Project (2013.-2016.), koji je igrao ključnu ulogu u daljnjem razvoju usluga Europeane. Kao „Best Practice Network” u koordinaciji Zaklade Europeana, projekt je uspostavio digitalnu infrastrukturu u oblaku za objedinjavanje sadržaja europske kulturne baštine. Jedan od najvažnijih rezultata projekta bilo je stvaranje nove usluge Europeana Research za istraživače s područja digitalne humanistike. ${ }^{14}$

Suradnja s internetskom platformom Getty Research Portal, koja omogućuje pristup digitaliziranim tekstovima s područja povijesti umjetnosti, donijela je sadržajima Digitalne zbirke i Arhiva za likovne umjetnosti globalnu vidljivost. Portal se sastoji od metapodataka koji su povezani s digitaliziranim tekstovima na mrežnim stranicama ustanova ili njihovih pružatelja usluga, među kojima se od 2017. nalazi i Hrvatska akademija znanosti i umjetnosti. Trenutačno GRP sadrži 482 zapisa iz Digitalne zbirke, uključujući digitalizirane kataloge izložbi i hrvatske umjetničke časopise. ${ }^{15}$

Želja da se spriječi raspršenost digitalnih sadržaja i podataka koje proizvode različite domaće AKM ustanove rezultirala je projektom tematskog portala znameniti.hr, koji je pokrenula Akademijina knjižnica. ${ }^{16}$ Okupljajući digitalnu građu različitih repozitorija povezanu s važnim osobama hrvatske kulture, znanosti, umjetnosti i javnog života, projekt nastoji osigurati istraživačima i široj javnosti veću dostupnost i bolju upotrebu nekomercijalnih znanstvenih, kulturnih i umjetničkih digitalnih sadržaja. Arhiv za likovne umjetnosti do sada je pridonio metapodacima o nekolicini poznatih hrvatskih umjetnika: Menciju Klementu Crnčiću, Tomislavu Krizmanu, Frani Kršiniću, Celestinu Medoviću, Slavi Raškaj, Nasti Rojc, Ivanu Meštroviću i Rudolfu Valdecu. Godine 2018. portal znameniti.hr otvoren je široj regiji projektom Okviri suradnje digitalnih infrastruktura u regiji-mogućnosti i potrebe na primjeru građe o znamenitim ličnostima znanosti i kulture, ${ }^{17}$ u cilju uključivanja hrvatskih, slovenskih i bosanskih ustanova u raspravu o korištenju digitalnom infrastrukturom u regionalnim kulturnim i znanstvenim zajednicama. Projektnu skupinu činile su hrvatske ustanove s projekta znameniti.hr te partneri iz Slovenije (Znanstvenoraziskovalni center Slovenske akademije znanosti in umetnostiZRCSAZU) i Bosne i Hercegovine (Zemaljski muzej Bosne i Hercegovine-ZMBiH; Nacionalna i univerzitetska biblioteka Bosne i Hercegovine-NUBBiH). Rezultat ovog jednogodišnjeg projekta bila je testna platforma eminentpeople.eu. dence, exhibition documentation, personal photographs). Beyond the opportunity to present archival material to a much wider audience, virtual exhibition projects empower the art information professionals to become "storytellers" who will subjectively choose a specific artefact and bring it to the public eye, while keeping in mind their professional responsibility to present reliable and valuable archival sources.

\section{COLLABORATIVE PROJECTS: FROM NATIONAL TO INTERNATIONAL}

The ongoing digitization process of the Academy holdings has opened up new opportunities for collaboration with national and international institutions through several projects. DiZbi was one of the metadata providers for the Europeana Cloud Project (2OI3-20I6), which played a vital role in the further development of Europeana's services. As a Best Practice Network, coordinated by the Europeana Foundation, the project established a cloud-based digital infrastructure for aggregating European cultural heritage content. One of the most important project deliverables was the creation of Europeana Research, a new service supporting researchers in the digital humanities. ${ }^{14}$

14

„Europeana Cloud". 15

"Contributors".

16

„Znameniti”. Na projektu surađuju sljedeće nacionalne ustanove: Hrvatska akademija znanosti i umjetnosti (HAZU), Nacionalna i sveučilišna knjižnica (NSK), Knjižnice grada Zagreba (KGZ), Državni arhiv u Varaždinu (DAVŽ), Leksikografski zavod Miroslav Krleža (LZMK), Muzej za umjetnost i obrt (MUO), Institut za etnologiju i folkloristiku (IEF), ICARUS.HR i ArhivPro d.o.o. 17

"Cooperation Framework of Digital Infrastructure in the Region - Opportunities and Needs in Case of Material Concerning Famous People in Science and Culture". 18

"Pharos".

19

DARIAH-HR".

20

Cuadra, Penot, „The Goupil Stock Books Project”; „Agnew's

Stock Books”; Crookham, Dunn, „Reframing Art: Opening Up Art Dealers' Archives to Multi-disciplinary Research”; „German Sales 1901-1945”. 21

Do sada su digitalizirane četiri knjige Arhiva Salona Ullrich. 
Svi navedeni projekti pokušavaju riješiti jedan od glavnih problema digitalizacije znanstvene i kulturne baštine-kako povezati digitalne sadržaje u virtualne zbirke bez obzira na rasutost njihovih fizičkih pandana po raznim ustanovama širom svijeta. Što se tiče povijesti umjetnosti, dobar je primjer platforma Pharos, koju je stvorio konzorcij od četrnaest europskih i sjevernoameričkih fotografskih arhiva na području povijesti umjetnosti, s više od dvadeset pet milijuna javno dostupnih slika umjetničkih djela i srodne dokumentacije koji se mogu pretraživati. ${ }^{18}$ Takav je portal potreban i na nacionalnoj hrvatskoj razini, jer to bi zacijelo povećalo vidljivost i povezivost vizualne umjetničke građe s podacima, znatno olakšavajući istraživanje na terenu i nudeći velike podatke za buduće projekte na području digitalne povijesti umjetnosti. Kao primjer dobre prakse, infrastruktura DARIAH-EU ${ }^{19}$ mogla bi poslužiti kao platforma za rješavanje navedenih pitanja.

DIGITALIZACIJA

\section{ARHIVA SALONA ULLRICH}

U posljednjih nekoliko godina tržišta umjetnina, kolekcionari i mobilnost umjetničkih djela sve više dospijevaju u fokus istraživanja, uz dodatnu podršku digitalnih humanističkih alata koji omogućuju aktivnosti poput statističke analize i vizualizacije podataka. Nekoliko europskih i američkih projekata trenutačno se bavi digitalizacijom i obogaćivanjem metapodataka kao potporom istraživanju tržišta umjetnina. ${ }^{20}$ Arhiv Salona Ullrich jedna je od najdragocjenijih zbirki Arhiva za likovne umjetnosti, a ujedno jedina cjelovito očuvana dokumentacija povezana s tržištem umjetnina iz njegova formativnog razdoblja u Hrvatskoj početkom 20. stoljeća. Ullrichov arhiv, koji sadrži dokumentaciju o djelovanju galerije od 1910. do 1948. godine, od velike je važnosti za ovu istraživačku temu, s obzirom na to da potencijalno pruža analitičke i sintetičke uvide u složene međuodnose umjetnika, trgovaca umjetninama i kolekcionara. lako je projekt Arhiva za likovne umjetnosti još uvijek u ranoj fazi digitalizacije knjiga inventara, izložbi i komisije (sl. 4), ${ }^{21}$ kontinuirano se planiraju sljedeće faze koje će uključiti transkripciju, istraživanje i organizaciju složenih metapodataka za primjenu u analizi i vizualizaciji podataka.

16

"Znameniti." The Croatian institutions collaborating on the project are the Croatian Academy of Sciences and Arts (HAZU), National and University Library (NSK), Zagreb City Libraries (KGZ), State Archive in Varaždin (DAVŽ), Miroslav Krleža Institute of Lexicography (LZMK), Museum of Arts and Crafts (MUO), Institute of Ethnology and Folklore Research (IEF), ICARUS.HR, and ArhivPro d.o.o.

"Cooperation Framework of Digital Infrastructure in the Region-Opportunities and Needs in Case of Material Concerning Famous People in Science and Culture." 18

"Pharos."

19

"DARIAH-HR."
Collaboration with the Getty Research Portal, an online platform providing access to digitized art history texts, brought DiZbi and the Fine Arts Archives' digital content global visibility, after the Academy became one of the GRP contributors in 20I7. The Portal is comprised of metadata that link to digitized texts hosted by the contrib uting institutions or their service providers. There are currently 482 records from DiZbi at GRP, including digitized exhibition catalogues and Croatian art journals. ${ }^{15}$

A desire to address the scattering of digital objects and data produced by various national GLAM institutions resulted in the Academy Library initiating a thematic portal, znameniti.hr. ${ }^{16}$ By gathering together digital material on the important personalities from Croatian culture, science, art, and public life from different repositories, the purpose of the project is to provide greater accessibility and better use of non-commercial scholarly, cultural, and artistic digital content for researchers and the general public. The Fine Arts Archives has so far contributed with metadata on some famous Croatian artists, namely Menci Clement Crnčić, Tomislav Krizman, Frano Kršinić, Celestin Medović, Slava Raškaj, Nasta Rojc, Ivan Meštrović, and Rudolf Valdec. In 20I8, znameniti.hr opened up to a wider region through the project Cooperation Framework of Digital Infrastructure in the Region - Opportunities and Needs in Case of the Material Concerning Famous People in Science and Culture, ${ }^{17}$ with the goal of engaging Croatian, Slovenian, and Bosnian institutions in a discussion regarding the use of digital infrastructure in cultural and scholarly regional communities. The project group consisted of the Croatian institutions from the znameniti.hr project and partners from Slovenia (Research Centre of the Slovenian Academy of Sciences and Arts-ZRCSAZU) and Bosnia and Herzegovina (National Museum of Bosnia and Herzegovina-ZMBiH; National and University Library of Bosnia and Herze govina-NUBBiH). The result of this one-year project was a test platform, eminentpeople.eu.

All of the above projects have been trying to solve one of the main problems concerning digitized scholarly and cultural heritage research material-how to connect digital items in virtual collections, regardless of the distribution of their physical counterparts across various institutions all over the world. In terms of art history, a good example is the Pharos platform, created by a consortium of fourteen European and North American art historical photo archives, with more than twenty-five million publicly available and searchable images and related documentation. $^{18}$ There is a need for such a portal on the national level of Croatia as well, since it would certainly increase the visibility and connectivity of art images and data, considerably facilitating research in the field and providing big data for future digital art history projects. As an example of best practice, the DARIAH-EU infrastructure ${ }^{19}$ could serve as a platform for the realization of above-mentioned issues. 
Pripremljen je nacrt idejnog modela, u cilju da se definiraju međuodnosi osoba s različitim ulogama (umjetnici i kupci/ kolekcionari) i njihova povezanost s određenim umjetničkim djelom i njegovim skupom metapodataka. U slučaju uspješne primjene, prva hrvatska baza podataka o umjetničkoj provenijenciji stvorit će čvrste temelje za istraživanje početaka tržišta umjetnina u Hrvatskoj, pridonoseći tako polju međunarodnih istraživanja umjetničke provenijencije.

\section{ZAKLJUČAK}

U procesu digitalizacije hrvatske kulturne baštine, koji se služi najsuvremenijim metodama, artikuliranje opisnih skupova metapodataka za digitalizirane umjetničke tekstove i predmete ostaje glavni, još uvijek neriješen problem. Naime, ne postoji nijedan postojeći tezaurus koji bi služio kao vrijednosni podatkovni standard za opisna polja metapodataka kao što su razdoblje, predmet ili ključne riječi, a kamoli koncepti ili odnosi među njima. lako se praznina privremeno popunjava primjenom standarda bibliografskih metapodataka, budući međuinstitucionalni projekti mogli bi donijeti mnoge nepredvidive probleme. Trebalo bi što skorije definirati i formirati nekoliko vrsta umjetničkih rječnika prema sličnim, već etabliranim međunarodnim rječnicima kao što su Getty CDWA (Categories for the Description of Works of Art), IA (Iconography Authority) ili RKD Iconclass.

Imajući na umu izjavu stručnjakinje za digitalnu humanistiku Johanne Drucker kako digitalizacija nije reprezentacija, nego interpretacija, ${ }^{22}$ uloga stručnjaka za digitalnu povijest umjetnosti očito postaje sve proaktivnija-u proces digitalizacije mora biti uključeno više vrsta stručnog znanja, od odabira sadržaja do obogaćivanja podataka. Kako bi se napravio pomak prema kvalitetnijim rezultatima u takvom procesu, GLAM institucije i istraživačka zajednica trebali bi uže surađivati, posebice u Hrvatskoj, gdje standardi metapodataka za digitalnu povijest umjetnosti još nisu u potpunosti definirani i organizirani.

\section{DIGITIZATION}

OF THE SALON ULLRICH ARCHIVES

In the past few years, art markets, collectors, and the mobility of artworks have increasingly come into the focus of research, with the additional support of digital humanities tools supporting activities such as statistical analysis and data visualization. Several European and American projects are currently dealing with digitization and metadata enrichment in support of art market research. ${ }^{20}$ The Salon Ullrich Archives, one of the most valuable holdings of the Fine Arts Archives, is the only well-preserved, comprehensive documentation of the formation period of the art market in Croatia at the beginning of the 2oth century. These archives, comprising documentation covering the gallery's activities from I9IO to I948, are of great importance for this research topic, potentially providing analytic and synthetic insights into the complex interrelations between artists, art dealers, and art collectors. Although the digitization of the Salon Ullrich Archives is still in the early stage of digitizing gallery stock books (Fig. 4), ${ }^{21}$ planning the next stages is an ongoing process that will include transcription, research, and organization of complex metadata to be used for data analysis and visualization. 


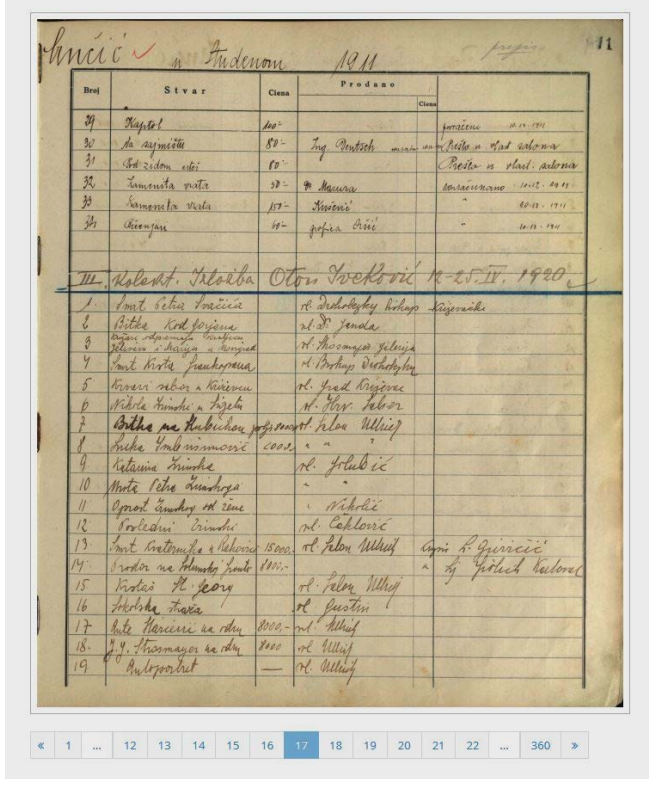

Slika 4. Knjiga izložbi Salona Ullrich (1910.-1927., str.11), Arhiv Salona Ullrich, Arhiv za likovne umjetnosti HAZU (neobjavljeno) / Figure 4. Salon Ullrich stock book (I9IO-I927, p. II), Salon Ullrich Archives, Fine Arts Archives (unpublished)
A draft of the conceptual model has been prepared, with the goal of defining the interrelations between persons with different roles (artists and buyers /collectors) and connecting them to a specific work of art with its own metadata set. In case of successful implementation, the first Croatian provenance database will provide a firm foundation for the research on the beginnings of the art market in Croatia, thus contributing to the field of international provenance research.

\section{CONCLUSION}

In the state-of-the-art digitization process of Croatian cultural heritage, articulating the descriptive sets of metadata for digitized art texts and objects remains the main, as yet unsolved problem. Namely, there is no extant thesaurus to serve as a data value standard for descriptive metadata fields such as extent, subject, or keywords, let alone concepts or relations between them. Although the void has been temporarily filled by using bibliographic metadata standards, future inter-institutional projects could bring many unpredictable problems. There is an urgent need to define and form several types of art vocabularies, according to the similar and established international ones such as the Getty CDWA (Categories for the Description of Works of Art), IA (Iconography Authority), or RKD Iconclass.

Having in mind the digital humanities' scholar Johanna Drucker's statement that digitization is not representation but interpretation, ${ }^{22}$ the role of art information professionals is clearly becoming more proactive-more expertise has to be included in the digitization process, from the selection of artefacts to data enrichment. In order to make a shift towards better quality results in such a process, the GLAM institutions and the research community should collaborate more closely, especially in Croatia, where the metadata standards for digital art history are not yet completely defined and organized.
Cuadra, Penot, "The Goupil Stock Books Project;” "Agnew's Stock Books;" Crookham, Dunn, "Reframing Art: Opening Up Art Dealers' Archives to Multi-disciplinary Research;" "German Sales I9OI-I945.” 21

Four stock books of Salon Ullrich Archives have been digitized so far.

22

Drucker, „Is There a 'Digital' Art History?,” 12. 
„Agnew's Stock Books”. The National Gallery. Dostupno na/Available at: https://www.nationalgallery.org.uk/research/research-centre/ agnews-stock-books (pristupljeno 30. svibnja 2019./last accessed on May 30, 2019).

"Contributors". Getty Research Portal. Dostupno na/Available at: http://portal.getty.edu/contributors (pristupljeno 31. svibnja 2019. /last accessed on May 31, 2019).

"Cooperation Framework of Digital Infrastructure in the RegionOpportunities and Needs in Case of Material Concerning Famous People in Science and Culture". DARIAH-HR, 27. veljače 2018./February 27, 2018. Dostupno na/Available at: http://dariah.hr/en/eventsand-activities/cooperation-framework-of-digital-infrastructure-inthe-region-opportunities-and-needs-in-case-of-material-concerningfamous-people-in-science-and-culture/ (pristupljeno 31. svibnja 2019./last accessed on May 31, 2019).

„Croatian Smart Specialisation Strategy 2016.-2020.”. Dostupno na/Available at: https://s3platform.jrc.ec.europa.eu/documents/20182/ 222782/strategy_EN.pdf/e0e7a3d7-a3b9-4240-a651-a3f6bfaaf10e (pristupljeno 1. kolovoza 2019./last accessed on August 1, 2019).

Crookham, Alan, Dunn, Stuart. „Reframing Art: Opening Up Art Dealers' Archives to Multi-disciplinary Research”. Visual Resources 35 (2019.). Dostupno na/Available at: https://doi.org/10.1080/ 01973762.2019.1553447 (pristupljeno 30. svibnja 2019./last accessed on May 30, 2019).

Cuadra, Ruth, Penot, Agnès. „The Goupil Stock Books Project”. The Iris, 15. veljače 2017./February 15, 2017. Dostupno na/Available at: https://blogs.getty.edu/iris/dah_cuadra_penot/ (pristupljeno 30. svibnja 2019./last accessed on May 30, 2019).

„DARIAH-HR”. Dostupno na/Available at: http://dariah.hr/en/home/ (pristupljeno 31. svibnja 2019./last accessed on May 31, 2019).

Der-Hazarijan Vukić, Andreja. „Arhiv za likovne umjetnosti Hrvatske akademije znanosti i umjetnosti: 1937.-2016." [Fine Arts Archives at the Croatian Academy of Sciences and Arts: 1937-2016]. $\mathrm{U} / \mathrm{In}$ : 4. kongres hrvatskih povjesničara umjetnosti (Zagreb, 24.-26. studenoga 2016.), knjižica sažetaka/book of abstracts, ur./ed. Krešimir Juraga. Zagreb: Društvo povjesničara umjetnosti Hrvatske-Institut za povijest umjetnosti, 2016.

Der-Hazarijan Vukić, Andreja, Bogdan Ferber, Jasenka, Alujević, Darija. „Virtualne izložbe Arhiva za likovne umjetnosti HAZU” [Virtual exhibitions of the Fine Arts Archives at HAZU]. @rhivi 4 (2018.): 21-22.

„DiZbi.HAZU”. Dostupno na/Available at: http://dizbi.hazu.hr/ (pristupljeno 14. listopada 2019./last accessed on October 14, 2019).

Drucker, Johanna. „Is There a ,Digital' Art History?”. Visual Resources 29/1-2 (2013.): 5-13. Dostupno na/Available at: https://doi.org/10.1080/ 01973762.2013.761106 (pristupljeno 30. svibnja 2019./last accessed on May 30,2019$)$. 
Ferber Bogdan, Jasenka. „Digitization of the Ullrich Salon Archive

-The Challenges of a New Medium", 31. U/In: International Interdisciplinary Scientific Conference Heritage Culture and Digital Humanities - A Bond between the Old and the New (Osijek, May 19-20, 2017), knjižica sažetaka/book of abstracts, ur./ed. Tihomir Živić. Osijek: Sveučilište u Osijeku, Odjel za kulturologiju, 2017.

. „The First Virtual Exhibition on DIZBI-Picasso's 80th Birthday”, Pregled Nacionalnog centra za digitalizaciju 25 (2014.): 75-80.

Ferber Bogdan, Jasenka, Getaldić, Magdalena, Turković-Krnjak, Filip. „Visual Art Resources at Digital Collection of Croatian Academy of Sciences and Arts: Supporting Digital Art History", 17. U/In: 2nd International Symposium on Digital Humanities: Empowering Visibility of Croatian Cultural Heritage (Zadar, November 6-8, 2017), knjižica sažetaka/book of abstracts. Zadar: University of Zadar, 2017.

Fletcher, Pamela. „Reflections on Digital Art History”. caa. reviews (18. lipnja 2015./June 18, 2015). Dostupno na/Available at: http://dx.doi. org/10.3202/caa.reviews.2015.73 (pristupljeno 30. svibnja 2019./last accessed on May 30, 2019).

„German Sales 1901-1945”. Arthistoricum. Dostupno na/Available at: https://www.arthistoricum.net/en/about-us/ (pristupljeno 30. svibnja 2019./last accessed on May 30, 2019).

Gotti, Sofia, Ilić, Marko. „Point of Origin: from a History of Alternative Art to a History of Alternative Institutions", 71-92. U/In: Collaboration and its (Dis)Contents. Art, Architecture, and Photography since 1950, ur./ed. Meredith A. Brown, Michelle Millar Fisher. London: Research Forum of The Courtauld Institute of Art, 2017. Dostupno na/Available at: https://courtauld-website.s3.amazonaws.com/pub/e-books/ cbo/Collaboration_and_its_Dis_Contents_Art_A.pdf (pristupljeno 31. svibnja 2019./last accessed on May 31, 2019).

Guilledoux, Fred. „Joyeux anniversaire, ,Pablo de Vallauris'!”. La Provence-Histoire 4 (2016.): 128-131.

Ilić, Marko. „Made in Yugoslavia. Struggles with Self-management in the New Art Practice, 1965-71". ARTMargins 8/1 (2019.): 6-30. Dostupno na/Available at: https://doi.org/10.1162/artm_a_00225 (pristupljeno 1. kolovoza 2019./last accessed on August 1, 2019).

Juričić, Vedrana. „Digital Collection of Croatian Academy of Sciences and Arts". Pregled Nacionalnog centra za digitalizaciju 21 (2012.): 65-74.

Juričić, Vedrana, Crnković, Kristijan. „U potrazi za baštinom: digitalna zbirka Hrvatske akademije znanosti i umjetnosti" [In search of heritage: Digital Collection at the Croatian Academy of Sciences and Arts]. Muzeologija 48/49 (2012.): 295-306.

Kolešnik, Ljiljana. „Digital Art History-Features, Problems and Prospects”. Život umjetnosti 99 (2016.): 10-19.

„Pablo Picasso: Proslava osamdesetog rođendana-Vallauris 1961." DiZbi. Dostupno na/Available at: http://dizbi.hazu.hr/picasso/ (pristupljeno 30. svibnja 2019./last accessed on May 30, 2019).
"Pharos". Dostupno na/Available at: http://pharosartresearch.org/ (pristupljeno 31. svibnja 2019./last accessed on May 31, 2019).

„Picasso, 'a genius without a pedestal'”. Mucem. Dostupno na / Available at: http://www.mucem.org/en/picasso-geniuswithout-pedestal (pristupljeno 30. svibnja 2019./last accessed on May 30, 2019).

"Prvi svjetski rat-iz zbirki Hrvatske akademije znanosti i umjetnosti”. DiZbi. Dostupno na/Available at: http://dizbi.hazu.hr/1st_world_ war/ (pristupljeno 30. svibnja 2019./last accessed on May 30, 2019).

"Salon Ullrich: prva zagrebačka privatna galerija”. DiZbi.

Dostupno na/Available at: http://dizbi.hazu.hr/ullrich/ (pristupljeno 30. svibnja 2019./last accessed on May 30, 2019).

Sotirova, Kalina, Peneva, Juliana, Ivanov, Stanislav, Doneva, Rositza, Dobreva, Milena. „Chapter 1: Digitization of Cultural Heritage -Standards, Institutions, Initiatives", 23-68. U/In: Access to Digital Cultural Heritage: Innovative Applications of Automated Metadata Generation, ur./ed. Krassimira Ivanova, Milena Dobreva, Peter Stanchev, George Totkov. Plovdiv: Plovdiv University Publishing House „Paisii Hilendarski”, 2012.

Vitković, Zrinka. „Portal Digitalna zbirka Hrvatske akademije znanosti i umjetnosti" [The Digital Collection portal at the Croatian Academy of Sciences and Arts]. Vjesnik bibliotekara Hrvatske 55 (2012.): 121-136.

„Znameniti”. Dostupno na/Available at: http://znameniti.hr/ (pristupljeno 31. svibnja 2019./last accessed on May 31, 2019). 